\title{
INFLUENCE OF MINERAL SALTS UPON ACTIVITY OF TRICHODERMA HARZIANUM NON-VOLATILE METABOLITES ON ARMILLARIA SPP. RHIZOMORPHS
}

\author{
Krystyna PRZYbyŁ ${ }^{1}$, MAŁgorzata MAŃKA ${ }^{2}$ \\ ${ }^{1}$ Polisch Academy of Sciences, Institute of Dendrology \\ Parkowa 5, 62-035 Kórnik, Poland \\ e-mail:kmtprz@man.poznan.pl \\ ${ }^{2}$ August Cieszkowski University of Agriculture, Department of Forest Pathology \\ Wojska Polskiego 71C, 60-625 Poznań, Poland
}

(Received: February 9, 2004. Accepted: August 31, 2004)

\begin{abstract}
Effect of non-volatile metabolites of Trichoderma harzianum together with certain salts containing $\mathrm{Mg}^{++}$, $\mathrm{Fe}^{+++}, \mathrm{Mn}^{++}, \mathrm{Cu}^{++}, \mathrm{Al}^{+++}, \mathrm{Ca}^{++}, \mathrm{K}^{++}, \mathrm{Na}^{+}, \mathrm{PO}_{4}^{---}$and $\mathrm{SO}_{3}{ }^{---}$on the production and length of rhizomorphs of Armillaria borealis, A. gallica and A. ostoyae was studied. In pure medium, T. harzianum exhibited stimulating effect on rhizomorphs of $A$. borealis (both number and length) and A. ostoyae (only initiation).

$\mathrm{Cu}^{++}$salt totaly inhibited the initiation of rhizomorphs of Armillaria borealis, A. gallica and A. ostoyae. Effect of other compounds on the activity of T. harzianum depended on Armillaria species. The majority of chemical compounds tested supressed the activity of non-volatile metabolites of T. harzianum. Evident stimulating effect was observed under influence of sulphate salts consisting $\mathrm{Al}^{++}$and $\mathrm{Fe}^{+++}$on the rhizomorph number of A. borealis and A. gallica, respectively.
\end{abstract}

KEY WORDS: rhizomorphs, Armillaria borealis, Armillaria gallica, Armillaria ostoyae, Trichoderma harzianum, mineral salts.

\section{INTRODUCTION}

Root rot caused by Armillaria species is a common and severe disease of coniferous and deciduous trees (Rykowski 1981; Rishbeth 1988; Termorshuizen and Arnolds 1994; Rosso and Hansen 1998; Przybył 1999; Żółciak 1999; Selochnik and Kondrashova 2002; Thomas et al. 2002).

Rhizomorphs of Armillaria spp. play a major role in both the infection and spread of the disease, however, spore infection and root contacts are also considered in both processes (Rishbeth 1988). Distribution of Armillaria spp. and growth of rhizomorphs depend on many environmental factors, from which the effect of several soil factors, e.g. $\mathrm{pH}$, moisture and organic matter on rhizomorph initiation and growth were most often empasized (Rishbeth 1978; Rykowski 1981; Pritam 1983; Twery et al. 1990; Shaw and Kile 1991; Marçais and Wargo 2000).

Some authors claim that suppression or stimulation of Armillaria spp. and other many pathogenic fungi is connected with metabolites produced by soil microorganisms, e.g. Trichoderma spp. (mainly T. harzianum Rifai and T. viride Pers. et Gray), Aureobasidium pullulans (de Bary) Arn. and Zygorrhynchus moelleri Vuill. (Pentland 1965; Kelly
1976; Harrison and Stewart 1988; Anselmi et al. 1992; Fox et al. 1994; Gallet and Lung-Escarmant 1994; Kwaśna and Łakomy 1998; Languasco et al. 2001). To our knowledge there is very little information available in the literature on the effect of inorganic compounds in pathogen-microorganism interaction.

The aim of our study reported here was to establish the in vitro effect of non-volatile metabolites of Trichoderma harzianum grown on medium with some mineral salts on production (expressed in their number) and growth (expressed in their length) of rhizomorphs of A. ostoyae (Romag.) Herink, A. borealis Marx. et Korh. and A. gallica Marx. et Romag.

\section{MATERIALS AND METHODS}

\section{Fungal material}

Isolates of Armillaria spp. were obtained from roots showing distinct decay symptoms, of the following tree species: Quercus robur L. (A. borealis and A. gallica) and Picea abies Karst. (A. ostoyae). Trichoderma harzianum belonged to fungi which were also detected in roots affected by Armillaria spp. The isolation of fungi and identification 
procedure of Armillaria spp. described by Korhonen (1978) and Przybył (1999) was used, respectively.

The cultures were stored ca. 12 months on $3.5 \%$ malt extract agar (MEA; Merck, $\mathrm{pH} 5.3$ ) at $+3^{\circ} \mathrm{C}$ before the study. They were transferred onto fresh MEA and then incubated in the dark at $23-24^{\circ} \mathrm{C}$. All studied isolates of Armillaria species were able to form rhizomorphs under these conditions.

In the preliminary study, the non-volatile metabolites of three T. harzianum isolates were tested on MEA. They exhibited significant stimulating effect on rhizomorphs of A. borealis (both number and length) and A. ostoyae (number). In the case of $A$. gallica the effect was not visible in comparison with control data (results are included in Tables 1, 2 and 3). The difference in effect of the Trichoder$m a$ isolates on the formation and length of rhizomorphs was not significant. Therefore only one isolate was randomly selected for further studies.

\section{Effect of chemical compounds - experiment 1 $(M E A+C)$}

The following chemical compounds were applied: $\mathrm{Mg}-$ $\mathrm{MgSO}_{4} \times 7 \mathrm{H}_{2} \mathrm{O}, \mathrm{Fe}-\mathrm{Fe}_{2}\left(\mathrm{SO}_{4}\right)_{3} \times 7 \mathrm{H}_{2} \mathrm{O}, \mathrm{Mn}-\mathrm{Mn} \mathrm{SO} \mathrm{SO}_{4} \times$ $5 \mathrm{H}_{2} \mathrm{O}, \mathrm{Cu}-\mathrm{Cu} \mathrm{SO} \mathrm{SO}_{4} \times 5 \mathrm{H}_{2} \mathrm{O}, \mathrm{Al}-\mathrm{Al}_{2}\left(\mathrm{SO}_{4}\right)_{3}, \mathrm{Ca}-\mathrm{CaCl}_{2}$, $\mathrm{K}-\mathrm{KCl}, \mathrm{P}-\mathrm{KH}_{2} \mathrm{PO}_{4}, \mathrm{Na}-\mathrm{NaCl}, \mathrm{S}-\mathrm{Na}_{2} \mathrm{SO}_{3}$ and $\mathrm{K}_{2} \mathrm{SO}_{3}$ (Ważny 1963; Sierota 1983). Mineral salts solutions at concentration $100 \mathrm{ppm}$ of examined compounds were passed individually through $0.22 \mu \mathrm{m}$ Millipore (Bedford, MA) filter and then separately added into steriled MEA. The $\mathrm{pH}$ of media were adjusted to 5.3 with $0.1 \mathrm{~N} \mathrm{NaOH}$ or $\mathrm{HCl}$

TABLE 1. Effect of some chemical compounds and Trichoderma harzianum on production and length of Armillaria borealis rhizomorphs.

\begin{tabular}{|c|c|c|c|}
\hline \multicolumn{2}{|c|}{ Compounds } & $\begin{array}{l}\text { Number } \\
\text { of rhizo- } \\
\text { morphs } \\
\text { (averages) }\end{array}$ & $\begin{array}{l}\text { Length of } \\
\text { rhizomorphs } \\
\text { (averages; } \\
\text { mm) }\end{array}$ \\
\hline & MEA & $5.0 \mathrm{~b}$ & 5.1 \\
\hline & $\mathrm{MEA}+\mathrm{T}$ & $18.6 \mathrm{~cd}$ & 18.4 \\
\hline (1) & Cupric sulfate $\left(\mathrm{CuSO}_{4} 5 \mathrm{H}_{2} \mathrm{O}\right)$ & $0.0 \mathrm{a}$ & $0.0 \mathrm{a}$ \\
\hline & Cupric sulfate $+\mathrm{T}$ & $0.0 \mathrm{a}$ & $0.0 \mathrm{a}$ \\
\hline (2) & Potassium sulphite $\left(\mathrm{K}_{2} \mathrm{SO}_{3}\right)$ & $9.1 \mathrm{bcd}$ & $2.0 \mathrm{ab}$ \\
\hline & Potassium sulphite $+\mathrm{T}$ & $9.3 \mathrm{bcd}$ & $6.8 \mathrm{cde}$ \\
\hline (3) & Manganese sulphate $\left(\mathrm{MnSO}_{4} 5 \mathrm{H}_{2}\right)$ & $8.5 \mathrm{bcd}$ & $2.3 \mathrm{abc}$ \\
\hline & Manganese sulphate $+\mathrm{T}$ & $10.3 \mathrm{bcd}$ & 3.0 bcdef \\
\hline (4) & Magnesium sulphate $\left(\mathrm{MgSO}_{4} 5 \mathrm{H}_{2} \mathrm{O}\right)$ & $10.1 \mathrm{bcd}$ & 2.9 bcdef \\
\hline & Magnesium sulhate $+\mathrm{T}$ & $21.6 \mathrm{~d}$ & $10.2 \quad \mathrm{~h}$ \\
\hline$(5)$ & Aluminium sulphate $\mathrm{Al}_{2} \mathrm{SO}_{4}$ & $8.1 \mathrm{bc}$ & 3.0 bcdef \\
\hline & Aluminium sulphate $+\mathrm{T}$ & $33.3 \mathrm{e}$ & 3.1 bcdef \\
\hline (6) & Ferrous sulphate $\left(\mathrm{Fe}_{2}\left(\mathrm{SO}_{4}\right)_{3} 7 \mathrm{H}_{2} \mathrm{O}\right)$ & 13.9 & 3.6 bcdef \\
\hline & Ferrous sulphate $+\mathrm{T}$ & $19.6 \mathrm{~cd}$ & 4.9 cdefg \\
\hline (7) & Potassium hypophosphite $\left(\mathrm{KH}_{2} \mathrm{PO}_{4}\right)$ & 7.9 bc & $2.4 \mathrm{abc}$ \\
\hline & Potassium hypophosphite $+\mathrm{T}$ & $16.6 \mathrm{~cd}$ & 2.8 bcde \\
\hline (8) & Potassium chloride $(\mathrm{KCl})$ & $7.5 \mathrm{bc}$ & 2.7 bcde \\
\hline & Potassium chloride $+\mathrm{T}$ & $16.6 \mathrm{~cd}$ & 3.2 bcdef \\
\hline (9) & Sodium sulphite $\left(\mathrm{Na}_{2} \mathrm{SO}_{3}\right)$ & $9.6 \mathrm{bcd}$ & $2.2 \mathrm{ab}$ \\
\hline & Sodium sulphite $+\mathrm{T}$ & $16.6 \mathrm{~cd}$ & $7.3 \mathrm{gh}$ \\
\hline (10) & Sodium chloride $(\mathrm{NaCl})$ & $7.1 \mathrm{bc}$ & 3.0 bcdef \\
\hline & Sodium chloride $+\mathrm{T}$ & $11.0 \mathrm{bcd}$ & 4.6 cdefg \\
\hline (11) & Calcium chloride $\left(\mathrm{CaCl}_{2}\right)$ & $17.1 \mathrm{~cd}$ & $2.5 \mathrm{a}$ bcd \\
\hline & Calcium chloride $+\mathrm{T}$ & 16.0 & 4.6 cdefg \\
\hline
\end{tabular}

Data followed by the same letters do not differ significantly $(\mathrm{p}=0.05)$ with Duncan test

MEA - Malt extract agar; T - Trichoderma harzianum

Mineral salts were composed of: (1) $-\mathrm{Cu},(2)-\mathrm{S}$, (3) - Mn, (4) $-\mathrm{Mg}$, (5) $-\mathrm{Al},(6)-\mathrm{Fe},(7)-\mathrm{P},(8)-\mathrm{K},(9)-\mathrm{S},(10)-\mathrm{Na},(11)-\mathrm{Ca}$ using the Microcomputer pH-meter Cp-315 (Dhingara and Sinclair 1986).

Medium plugs of three isolates of each Armillaria species measuring approximately $5 \mathrm{~mm}$ by $5 \mathrm{~mm}$ were placed in the centre of a Petri dishes containing MEA with individual mineral salts. Seven replications were made for each isolate. Cultures were then incubated at $23^{\circ} \mathrm{C}$. The average number of rhizomorphs and their mean length were measured after 26 days. In the second case the length of all rhizomorphs was calculated per one rhizomorph for each culture.

\section{Effect of non-volatile metabolites of T. harzianum - experiment 2}

Non-volatile metabolites produced by T. harzianum were tested using the procedure described by Dennis and Webster (1971) and Rudawska et al. (1993). The fungus was grown from its inoculum disk over the surface of cellophane membrane laid on pure MEA $(\mathrm{MEA}+\mathrm{T})$ and on MEA containing separately added salts $(\mathrm{MEA}+\mathrm{T}+\mathrm{C})$.

Metabolites produced by $T$. harzianum were allowed to diffuse through the cellophane into medium. Plug mycelium (ca $5 \times 5 \mathrm{~mm}$ ) of Armillaria sp. was placed onto middle of each medium 6 days after the removal of the cellophane with T. harzianum. Mycelium of the Armillaria species was cut from colonies after 24 days of incubation on MEA at $23-24^{\circ} \mathrm{C}$. The activity of metabolites was assessed by measuring the number and length of rhizomorphs after 26 days in the same way as in experiment 1 . Seven replications for each isolate were performed.

TABLE 2. Effect of some chemical compounds and Trichoderma harzianum on production and length of Armillaria gallica rhizomorphs.

\begin{tabular}{|c|c|c|c|}
\hline \multicolumn{2}{|c|}{ Compounds } & $\begin{array}{c}\text { Number } \\
\text { of rhizo- } \\
\text { morphs } \\
\text { (averages) }\end{array}$ & $\begin{array}{l}\text { Length of } \\
\text { rhizomorphs } \\
\text { (averages; } \\
\text { mm) }\end{array}$ \\
\hline & MEA & 21.0 bcde & 21.2 \\
\hline & $\mathrm{MEA}+\mathrm{T}$ & 23.4 bcde & 25.4 \\
\hline (1) & Cupric sulphate $\left(\mathrm{CuSO}_{4} \times 5 \mathrm{H}_{2} \mathrm{O}\right)$ & $0.0 \mathrm{a}$ & $0.0 \mathrm{a}$ \\
\hline & Cupric sulphate $+\mathrm{T}$ & $0.0 \mathrm{a}$ & $0.0 \mathrm{a}$ \\
\hline (2) & Potassium sulphite $\left(\mathrm{K}_{2} \mathrm{SO}_{3}\right)$ & 30.2 cdef & $5.0 \mathrm{abcd}$ \\
\hline & Potassium sulphite $+\mathrm{T}$ & 28.3 & 11.3 defg \\
\hline (3) & Manganese sulphate $\left(\mathrm{MnSO}_{4} \times 5 \mathrm{H}_{2} \mathrm{O}\right)$ & 23.3 & 12.2 \\
\hline & Manganese sulphate $+\mathrm{T}$ & 29.6 cdef & 18.3 \\
\hline (4) & Magnesium sulphate $\left(\mathrm{MgSO}_{4} \times 5 \mathrm{H}_{2} \mathrm{O}\right)$ & $14.6 \mathrm{abc}$ & 4.9 abcd \\
\hline & Magnesium sulphate $+\mathrm{T}$ & $15.1 \mathrm{abc}$ & 24.6 \\
\hline (5) & Aluminium sulphate $\left(\mathrm{Al}_{2} \mathrm{SO}_{4}\right)$ & 28.0 cdef & $3.9 \mathrm{abc}$ \\
\hline & Aluminium sulphate $+\mathrm{T}$ & 20.6 bcde & 13.0 efg \\
\hline (6) & Ferrous sulphate $\left(\mathrm{Fe}_{2}\left(\mathrm{SO}_{4}\right)_{3} \times 7 \mathrm{H}_{2} \mathrm{O}\right)$ & 27.5 cdef & $4.8 \mathrm{abcd}$ \\
\hline & Ferrous sulphate $+\mathrm{T}$ & 45.6 & 14.0 efgh \\
\hline (7) & Potassium hypophosphite $\left(\mathrm{KH}_{2} \mathrm{PO}_{4}\right)$ & 26.1 & 4.8 abcd \\
\hline & Potassium hypophosphite $+\mathrm{T}$ & 20.3 bcde & 16.9 fgh \\
\hline (8) & Potassium chloride $(\mathrm{KCl})$ & 33.6 def & $2.8 \mathrm{ab}$ \\
\hline & Potassium chloride $+\mathrm{T}$ & 27.6 & 14.7 \\
\hline (9) & Sodium sulphite $\left(\mathrm{Na}_{2} \mathrm{SO}_{3}\right)$ & 24.2 & $5.1 \mathrm{abcd}$ \\
\hline & Sodium sulphite $+\mathrm{T}$ & 26.6 & 13.3 efg \\
\hline (10) & Sodium chloride $(\mathrm{NaCl})$ & 23.0 & $3.9 \mathrm{abc}$ \\
\hline & Sodium chloride $+\mathrm{T}$ & 18.6 bcde & 18.3 \\
\hline (11) & Calcium chloride $\left(\mathrm{CaCl}_{2}\right)$ & 18.6 bcdef & 4.5 abcd \\
\hline & Calcium chloride $+\mathrm{T}$ & 28.1 cdef & 18.2 \\
\hline
\end{tabular}

Data followed by the same letters do not differ significantly $(\mathrm{p}=0.05)$ with Duncan test

MEA - Malt extract agar; T - Trichoderma harzianum

Mineral salts were composed of: (1) $-\mathrm{Cu},(2)-\mathrm{S},(3)-\mathrm{Mn},(4)-\mathrm{Mg},(5)$

$-\mathrm{Al},(6)-\mathrm{Fe},(7)-\mathrm{P},(8)-\mathrm{K},(9)-\mathrm{S},(10)-\mathrm{Na},(11)-\mathrm{Ca}$ 
TABLE 3. Effect of some chemical compounds and Trichoderma harzianum on production and length of Armillaria ostoyae rhizomorphs.

\begin{tabular}{|c|c|c|c|}
\hline \multicolumn{2}{|c|}{ Compounds } & $\begin{array}{l}\text { Number } \\
\text { of rhizo- } \\
\text { morphs } \\
\text { (averages) }\end{array}$ & $\begin{array}{l}\text { Length of } \\
\text { rhizomorphs } \\
\text { (averages; } \\
\text { mm) }\end{array}$ \\
\hline & MEA & $3.6 \mathrm{abc}$ & $2.2 \mathrm{abc}$ \\
\hline & $\mathrm{MEA}+\mathrm{T}$ & $10.4 \mathrm{de}$ & $9.6 \mathrm{c}$ \\
\hline \multirow[t]{2}{*}{ (1) } & Cupric sulphate $\left(\mathrm{CuSO}_{4} \times 5 \mathrm{H}_{2} \mathrm{O}\right)$ & $0.0 \mathrm{a}$ & $0.0 \mathrm{a}$ \\
\hline & Cupric sulphate $+\mathrm{T}$ & $0.0 \mathrm{a}$ & $0.0 \mathrm{a}$ \\
\hline \multirow[t]{2}{*}{ (2) } & Potassium sulphite $\left(\mathrm{K}_{2} \mathrm{SO}_{3}\right)$ & $5.1 \mathrm{bcd}$ & $4.6 \mathrm{abc}$ \\
\hline & Potassium sulphite $+\mathrm{T}$ & $2.6 \mathrm{abc}$ & $9.6 \mathrm{c}$ \\
\hline \multirow[t]{2}{*}{ (3) } & Manganese sulphate $\left(\mathrm{MnSO}_{4} \times 5 \mathrm{H}_{2} \mathrm{O}\right)$ & $2.0 \mathrm{abc}$ & $4.0 \mathrm{abc}$ \\
\hline & Manganese sulphate $+\mathrm{T}$ & $4.0 \mathrm{abcd}$ & $2.5 \mathrm{abc}$ \\
\hline \multirow[t]{2}{*}{ (4) } & Magnesium sulphate $\left(\mathrm{MgSO}_{4} \times 5 \mathrm{H}_{2} \mathrm{O}\right)$ & $1.7 \mathrm{abc}$ & $3.5 \mathrm{abc}$ \\
\hline & Magnesium sulphate $+\mathrm{T}$ & $12.0 \quad \mathrm{e}$ & $11.8 \mathrm{c}$ \\
\hline \multirow[t]{2}{*}{ (5) } & Aluminium sulphate $\left(\mathrm{Al}_{2} \mathrm{SO}_{4}\right)$ & $3.6 \mathrm{abc}$ & $3.6 \mathrm{abc}$ \\
\hline & Aluminium sulphate $+\mathrm{T}$ & $11.0 \mathrm{de}$ & $4.5 \mathrm{abc}$ \\
\hline \multirow[t]{2}{*}{ (6) } & Ferrous sulphate $\left(\mathrm{Fe}_{2}\left(\mathrm{SO}_{4}\right)_{3} \times 7 \mathrm{H}_{2} \mathrm{O}\right)$ & $0.5 \mathrm{ab}$ & $1.0 \mathrm{ab}$ \\
\hline & Ferrous sulphate $+\mathrm{T}$ & $1.3 \mathrm{abc}$ & $3.6 \mathrm{abc}$ \\
\hline \multirow[t]{2}{*}{ (7) } & Potassium hypophosphite $\left(\mathrm{KH}_{2} \mathrm{PO}_{4}\right)$ & $3.2 \mathrm{abc}$ & $2.2 \mathrm{abc}$ \\
\hline & Potassium hypophosphite $+\mathrm{T}$ & \multirow{2}{*}{$\begin{array}{l}4.6 \text { bcd } \\
6.2 \text { cde }\end{array}$} & $2.7 \mathrm{abc}$ \\
\hline \multirow[t]{2}{*}{ (8) } & Potassium chloride $(\mathrm{KCl})$ & & $5.4 \mathrm{abc}$ \\
\hline & Potassium chloride $+\mathrm{T}$ & $9.6 \mathrm{de}$ & $4.6 \mathrm{abc}$ \\
\hline \multirow[t]{2}{*}{ (9) } & Sodium sulphite $\left(\mathrm{Na}_{2} \mathrm{SO}_{3}\right)$ & 6.7 cde & $6.1 \mathrm{abc}$ \\
\hline & Sodium sulphite $+\mathrm{T}$ & $2.7 \mathrm{abc}$ & $6.0 \mathrm{abc}$ \\
\hline \multirow[t]{2}{*}{ (10) } & Sodium chloride $(\mathrm{NaCl})$ & $3.1 \mathrm{abc}$ & $2.2 \mathrm{abc}$ \\
\hline & Sodium chloride $+\mathrm{T}$ & $2.6 \mathrm{abc}$ & $2.7 \mathrm{abc}$ \\
\hline \multirow[t]{2}{*}{ (11) } & Calcium chloride $\left(\mathrm{CaCl}_{2}\right)$ & \multirow{2}{*}{$\begin{array}{l}3.6 \mathrm{abcd} \\
5.0 \mathrm{bcd}\end{array}$} & $6.9 \mathrm{bc}$ \\
\hline & Calcium chloride $+\mathrm{T}$ & & $4.7 \mathrm{abc}$ \\
\hline
\end{tabular}

Data followed by the same letters do not differ significantly $(\mathrm{p}=0.05)$ with Duncan test

MEA - Malt extract agar; T - Trichoderma harzianum

Mineral salts were composed of: (1) - Cu, (2) - S, (3) - Mn, (4) - Mg, (5) $-\mathrm{Al},(6)-\mathrm{Fe},(7)-\mathrm{P},(8)-\mathrm{K},(9)-\mathrm{S},(10)-\mathrm{Na},(11)-\mathrm{Ca}$

Duncan's multiple range test (at a 5\% of significance level) was used to compare the means for all final data obtained in both experiments.

\section{RESULTS}

\section{Number of rhizomorphs}

Full inhibition of rhizomorphs initiation of all Armillaria species were observed in the medium containing $\mathrm{Cu}^{++}(\mathrm{Cu}-$ $\mathrm{SO}_{4}$ ) both without and with effect of $T$. harzianum metabolites.

Significantly greater number of $A$. borealis and A. gallica rhizomorphs occurred in the presence of $T$. harzianum together with $\mathrm{Al}^{+++}$and $\mathrm{Fe}^{+++}$(MEA + T + C; 33.3 and 45.6, respectively) in comparison with the number produced both on control media MEA $+\mathrm{T}$ and at MEA $+\mathrm{C}$ (Tables 1 and 2). The strong stimulating effect of $T$. harzianum metabolites together with the tested chemical compounds was not observed in the case of $A$. ostoyae rhizomorphs (Table $3)$. In this case the highest number of rhizomorphs (12.0) was found on medium containing Trichoderma metabolites together with $\mathrm{Mg}^{++}\left(\mathrm{MgSO}_{4}\right)$, but was not significantly differed from MEA+T. Whereas data relating to $\mathrm{Mg}^{++}$effect, and also to $\mathrm{Al}^{+++}(\mathrm{MEA}+\mathrm{C}+\mathrm{T})$ differed significantly from data obtained for cultures growing on MEA + C. Moreover statistic analysis revealed a significant inhibiting effect on rhizomorph number on media $(\mathrm{MEA}+\mathrm{T}+\mathrm{C})$ con- taining $\mathrm{Fe}^{+++}$(1.3), $\mathrm{Na}^{+}(2.6)$ and $\mathrm{SO}_{3}^{---}$in the form of both $\mathrm{K}_{2} \mathrm{SO}_{3}$ (2.6) and $\mathrm{Na}_{2} \mathrm{SO}_{3}(2.7)$ in comparison with the data obtained for MEA $+\mathrm{T}$ (Table 3 ).

\section{Length of rhizomorphs}

It should be emphasised that $\mathrm{Mn}^{++}, \mathrm{PO}_{4}^{---}$and $\mathrm{SO}_{3}^{---}$added to the medium alone, (without Trichoderma; MEA + C), significantly inhibited length of $A$. borealis rhizomorphs in pure medium (MEA; Table 1). A similar effect was obtained for A. gallica rhizomorphs being under influence of all individually tested compounds (Table 2).

Trichoderma effect on $A$. borealis rhizomorph length was inhibited by all individually investigated compounds (media $\mathrm{MEA}+\mathrm{C}+\mathrm{T}$ ) when the data were compared with those obtained for cultures growing in MEA $+\mathrm{T}$. On the other hand metabolites activity significantly increased under influence of $\mathrm{Mg}^{++}(10.2)$ and $\mathrm{SO}_{3}^{---}\left(\mathrm{K}_{2} \mathrm{SO}_{3}-6.8 . \mathrm{Na}_{2} \mathrm{SO}_{3}-7.3\right)$ (media MEA $+\mathrm{T}+\mathrm{C}$ ) in comparison with the activity in MEA + C (Table 1). In the A. gallica, inhibition of the metabolites activity was not noted in medium containing $\mathrm{Mg}^{++}(\mathrm{MEA}+\mathrm{T}+\mathrm{C}-24.6 \mathrm{~mm})$ in comparison with MEA $+\mathrm{T}(25.4 \mathrm{~mm})$. For majority of other compounds the significant effect of Trichoderma (MEA $+\mathrm{T}+\mathrm{C}$ ) occurred when it was compared with data obtained on medium MEA + C (Table 2). In the case of A. ostoyae no clear effect on the length of rhizomorphs was observed (Table 3 ).

\section{DISCUSSION}

In the opinion of Morrison (1982) larger number of initials and a faster growth rate of rhizomorphs of A. mellea is due to organic carbon and nitrogen present in the soil. Whereas Przybył (1998) found that sterilized soil rich in N, $\mathrm{P}, \mathrm{K}, \mathrm{Ca}$ and $\mathrm{Mg}$ more positively effected the initiation and length of rhizomorphs of $A$. ostoyae in comparison with $A$. borealis and A. gallica.

The results presented show, that $\mathrm{CuSO}_{4}$ (containing 100 ppm $\mathrm{Cu}^{++}$) inhibited the initiation of rhizomorphs of Armillaria borealis, A. gallica and A. ostoyae. The effect of other tested compounds on the activity of $T$. harzianum expressed in number and length of rhizomoprhs was dependent on Armillaria species. Generally, the majority of tested chemical compounds supressed activity of non-volatile metabolites of $T$ harzianum in comparison with results obtained in pure MEA + T. Stimulation of T harzianum activity was observed under influence of sulphate salts consisting $\mathrm{Al}^{++}$and $\mathrm{Fe}^{+++}$on the rhizomorph number of $A$. borealis and A. gallica, respectively. On the other hand $\mathrm{Fe}^{+++}$inhibited effect of $T$. harzianum on formation of $A$. ostoyae rhizomorphs. $\mathrm{Fe}^{+++}$salt, used in the study, is able to inhibit antagonistic ativity of certain fungi, e.g. Phlebiopsis gigantea toward Heterobasidion annosum (Negrutskiy et al. 1998). It is also proper to add that $\mathrm{Mg}, \mathrm{Mn}$ and $\mathrm{Zn}$ ions at a concentration of $100 \mathrm{ppm}$ increased the inhibitory effect of filtrates from $T$. viride cultures on $H$. annosum (Sierota 1983).

The authors are aware that the investigations presented, regarding only non-volatile metabolites, do not present an total effect of T. harzianum on rhizomorphs of tested $A r$ millaria spp. In general, T. harzianum and other Trichoderma spp. can act by activity of their non-volatile and volatile metabolites. Variation within $T$. harzianum isolates with 
regard to production of these metabolites was found by Dennis and Webster (1971); Harrison and Stewart (1988) and Rudawska et al. (1993). Moreover, mycoparasitism of T. harzianum on rhizomorphs of A. gallica was reported by Dumas and Boyonoski (1992). Undoubtedly, the activity of Trichoderma spp. by all the possible means can explain the antagonistic effect of $T$. harzianum against Armillaria species which was proved by Fox et al. (1994) and Languasco et al. (2001). On the other hand, Mughogo (1967, 1968, after Denis and Webster 1971) observed that isolates of $T$. harzianum did not affect the growth of $A$. mellea in vitro (in this case the complex of A. mellea was studied).

The results obtained for interaction of certain inorganic compouns with the pathogen and other microorganism ( $T$. harzianum) provide encouragement for further studies on this subject. Different concentrations of inorganic compounds should also be analysed.

\section{ACKNOWLEDGEMENTS}

This work was partially conducted within the project supported by the Central Board of State Forests in Warsaw and by the Instiute of Dendrology, Polish Academy of Sciences. The authors thank M. Wójkiewicz and M. Mikołajczyk for technical assistance.

\section{LITERATURE CITED}

ANSELMI N., NICOLOTTI G., SANQUINETI G. 1992. Antagonismo in vitro di Trichoderma spp. contro basidiomycetes agenti di marciumi radicali di piante forestali. Monti e Boschi 43: 57-67.

DENNIS C., WEBSTER J. 1971. Antagonistic properties of species-groups of Trichoderma. I. Production of non-volatile antibiotics. Trans. Br. Mycol. Soc. 57: 25-39.

DHINGARA O.D, SINCLAIR J.B. 1986. Basic plant pathology methods. CRC Press, Inc. Boca Raton, Florida: 1-355.

DUMAS M.T., BOYONOSKI N. 1992. Scanning electron microscopy of mycoparasitism of Armillaria rhizomorphs by species Trichoderma. Eur. J. For. Path. 22: 379-383.

GALLET J.P., LUNG-ESCARMANT B. 1994. Utilisation d'un biopesticide a base Trichoderma contre le pourridie-agari et plus specialement Armillaria ostoyae, parasite du pin maritime. Compt. Ren. Acad. Agr. France. 80: 151-162.

FOX R.T.V., MCQUE A.M., WEST J.S., RAZIG F. 1994. Use of antagonistic fungi to control Armillaria root rot. Brighton Crop Protection Conference, Pests and Diseases 3: 1115-1120.

HARRISON Y.A., STEWART A. 1988. Selection of fungal antagonists for biological control of onion white rot in New Zealand. New Zealand J. Exp. Agric. 16: 249-256.

KELLY W.D. 1976. Evaluation of Trichoderma harzianum - impregnated clay granules as a biocontrol for Phytophthora cinnamomi causing damping-off of pine seedlings. Phytopathology 66: 1023-1027.

KORHONEN K. 1978. Interfertility and clonal size in Armillaria mellea complex. Karstenia 18: 31-42.

KWAŚNA H., ŁAKOMY P. 1998. Stimulation of Armillaria ostoyae vegetative growth by tryptophol and rhizomorph formation by Zygorrhynchus moelleri. Eur. For. J. Path. 28: 53-63.

LANGUASCO L., PATTORI E., MINGUZZI A., SANSAVINI S. 2001. Evoluzione delle popolazioni edafiche di Trichoderma sp. introdotte in pescheti per la lotta contro Armillaria mellea (marciume radicale fibroso). XXIV Convegno Peschicolo. Per Una nuova peschicoltura: produzione, organizzazione, mercato. Cesena, Italia, 24-25 febbraio 2000: 165-167.
MARÇAIS B., WARGO P.M. 2000. Impact of liming on the abundance and vigor of Armillaria rhizomorphs in Allegheny hardwoods stands. Can. J. For. Res. 30: 1847-1857.

MORRISON D.J. 1982. Effect of soil organic matter on rhizomorph growth by Armillaria mellea. Trans. Brit. Mycol. Soc. 78: 201-208.

NEGRUTSKIY S.F., SOUKHOMLIN M.M., ZAPOROZCHENKO YE.V, DEMCHENKO S.I. 1998. The influence of $\mathrm{Fe}^{++}$ and $\mathrm{Fe}^{+++}$upon physiology and development of wood-attacking fungi. $9^{\text {th }}$ International Conference of Root and Butt Rots of Forest Trees, Carcans-Maubuisson (France), September 1-7, 1997. Ed. INRA, Paris: 341-347.

PENTLAND G.D. 1965. Stimulation of rhizomorph development of Armillaria mellea by Aureobasidium pullulans in artificial culture. Can. J. Microbiol. 11: 345-350.

PRITAM S. 1983. Armillaria root rot: influence of soil nutrients and $\mathrm{pH}$ on the susceptibility of conifer species to the disease. Eur. J. For. Path. 13: 92-101.

PRZYBYŁ K. 1998. Effects of soil inorganic nutrients on rhizomorph growth by Armillaria sp. $9^{\text {th }}$ International Conference of Root and Butt Rots of Forest Trees, Carcans-M aubuisson (France), September 1-7, 1997. Ed. INRA, Paris: 442 (Abstr.).

PRZYBYŁ K. 1999. Disease changes in root systems of Quercus robur L. and Betula pendula Rothr. trees and fungi identified in roots dead and showing decay. Zesz. Nauk. Akademii Rolniczej im. H. Kołłątaja w Krakowie 348: 143-152.

RISHBETH J. 1978. Effects of soil temperature and atmosphere on growth of Armillaria rhizomorphs. Trans. Brit. Mycol. Soc. 70: 213-220.

RISHBETH J. 1988. Stump infection by Armillaria in first-rotation conifers. Eur. J. For. Path. 18: 401-408.

ROSSO P., HANSEN E. 1998. Tree vigour and the susceptibility of Douglas fir to Armillaria root disease. Eur. J. For. Path. 28: 43-52.

RUDAWSKA M., PRZYBYŁ K., BOJARCZUK K. 1993. Integrated control of Phytophthora cinnamomi by Trichoderma viride and fungicydes on rooting of ericaceae plants. Biotechnologia 1: 51-55.

RYKOWSKI K. 1981. The influence of fertilizers on the occurrence of Armillaria mellea in Scots pine plantations. I. Evaluation of the health of fertilized and non-fertilized plantations and the variability of A. mellea in the areas investigated. Eur. J. For. Pathol. 11: 108-119.

SELOCHNIK N.N., KONDRASHOVA N.K. 2002. Armillaria complex in Russian forest steppe oak stands. Proceed. of the 5th Intern. Confer. 7-10 (13) October 2002, Moscow: 214-216.

SHAW C.G., KILE G.A. 1991. Armillaria Root Disease. Agriculture Handbook No. 691, United State Dep. Agric., Washington: 1-233.

SIEROTA Z. 1983. Wpływ niektórych soli mineralnych na rozwój Trichoderma viride Pers. ex Fr. in vitro. Prace Inst. Bad. Leś. 611: 67-79. (in Polish with English and Russian summary)

TERMORSHUIZEN A.J., ARNOLDS E.J.M. 1994. Geographical distribution of the Armillaria species in the Netherlands in relation to soil type and hosts. Eur. J. Pathol. 24: 129-136.

THOMAS F.M., BLANC R., HARTMAN G. 2002. Abiotic and biotic factors and their interactions as causes of oak decline in Central Europe. For. Pathol. 32: 277-307.

TWERY M.J., MASON G.N., WARGO P.M., GOTTSCHALK K.W. 1990. Abundance and distribution of rhizomorphs of Armillaria spp. in defoliated mixed oak stands in western Maryland. Can. J. For. Res. 20: 674-678.

WAŻNY J. 1963. Badania nad wpływem odżywiania mineralnego na wzrost grzybów Coniophora cerebella Pers. i Merulius lacrymans. Acta Soc. Bot. Pol. 32: 575-608. (in Polish with English summary)

ŻÓłCIAK A. 1999. Występowanie grzybów Armillaria (Fr.:Fr.) Staube w kompleksach leśnych w Polsce. Prace IBL 890: 29-40. (in Polish with English summary) 